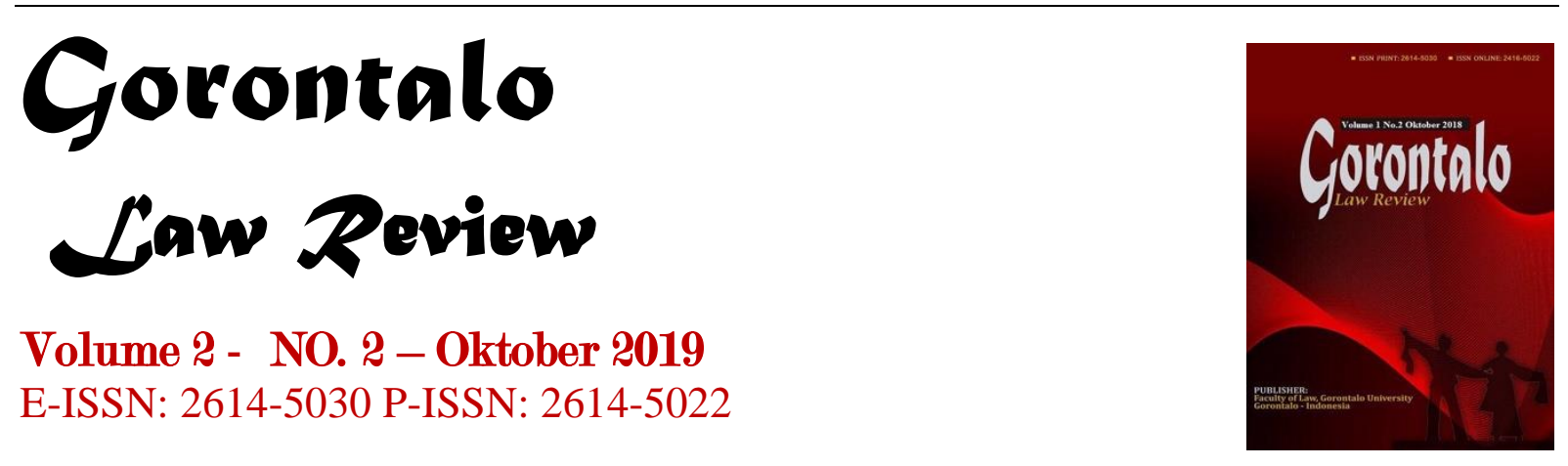

\title{
SIFAT KEBERLAKUAN ASAS ERGA OMNES DAN IMPLEMENTASI PUTUSAN MAHKAMAH KONSTITUSI
}

\author{
Fadzlun Budi Sulistyo Nugroho \\ Fakultas Hukum Universitas Negeri Semarang, \\ email : fadzlunbudi9944@gmail.com
}

\begin{abstract}
Abstrak
Mahkamah Konstitusi Indonesia dalam perjalanan sejarahnya juga tidak terbebas dari berbagai kendala. Putusan Mahkamah Konstitusi pada kenyataannya sering tidak difahami memiliki kekuatan sebagaimana sebuah undang-undang. Makalah ini ditulis menggunakan metode yuridis normatif dengan menekankan pendekatan filosofis dan historis. Berdasarkan asas erga omnes yang berlaku atas Putusan Mahkamah Konstitusi dan tanggapan dari masyarakat serta lembaga penyelenggara negara terhadap Putusan Mahkamah Konstitusi, hasilnya menunjukkan bahwa keberlakuan asas erga omnes lahir dari sifat final dan mengikatnya Putusan Mahkamah Konstitusi. Dari perspektif filosofis, Putusan Mahkamah Konstitusi seharusnya mengikat semua pihak, baik individu maupun institusi. Akan tetapi, dalam implementasinya beberapa masyarakat dan Lembaga penyelenggara negara tidak memberikan respon sebagaimana mestinya. Kondisi seperti itu mengarah pada kesimpulan bahwa pemahaman dan kesadaran berkonstitusi pada masyarakat dan lembaga penyelenggara negara masih rendah.
\end{abstract}

\section{Kata kunci: Kesadaran berkonstitusi; Mahkamah Konstitusi; Sifat Putusan; Putusan; Asas Erga Omnes}

\begin{abstract}
The Indonesian Constitutional Court in its historical journey is also not free from various obstacles. The decisions of the Constitutional Court in reality are not necessarily understood as a law. This paper uses the normative juridical method by emphasizing philosophical and historical approaches. Based on the erga omnes principle of the Constitutional Court's
\end{abstract}


decisions and the response of the public and state administrators to the decisions of the Constitutional Court, the results show that the validity of the erga omnes principle was born from the final and binding decisions of the Constitutional Court. From a philosophical perspective, a Constitutional Court decision must be binding on all parties, both individuals and institutions. However, in its implementation some public and state administrators did not respond accordingly. Such conditions lead to a conclusion that understanding and constitutional awareness in the society and institutions is still low.

\section{Keywords: Awareness of The Constitution; Constitutional Court; Character of Decision; Decision; The principle of Erga Omnes}

\section{PENDAHULUAN}

Ketentuan Pasal 24 ayat (2) UUD 1945 menyatakan, kekuasaan kehakiman dilakukan oleh sebuah Mahkamah Agung dan badan peradilan yang berada di bawahnya dalam lingkungan peradilan umum, lingkungan peradilan agama, lingkungan peradilan militer, lingkungan peradilan tata usaha negara, dan oleh sebuah Mahkamah Konstitusi. Berdasarkan ketentuan tersebut, Mahkamah Konstitusi merupakan salah satu pelaku kekuasaan kehakiman selain Mahkamah Agung. Kekuasaan kehakiman merupakan kekuasaan yang merdeka untuk menyelenggarakan peradilan guna menegakkan hukum dan keadilan. Dengan demikian, Mahkamah Konstitusi adalah suatu lembaga peradilan, sebagai cabang kekuasaan yudikatif, yang mengadili perkara-perkara tertentu yang menjadi kewenangannya berdasarkan ketentuan UUD 1945.

Berdasarkan Pasal 24C ayat (1) UUD 1945 yang ditegaskan kembali dalam Pasal 10 ayat (1) huruf a sampai dengan d UU 24/2003, kewenangan Mahkamah Konstitusi adalah menguji undang-undang terhadap UUD 1945; memutus sengketa kewenangan lembaga negara yang kewenangannya diberikan oleh UUD 1945; memutus pembubaran partai politik; dan memutus perselisihan tentang hasil pemilihan umum. Selain itu, berdasarkan Pasal 7 ayat (1) sampai dengan (5) dan Pasal 24C ayat (2) UUD 1945 yang ditegaskan lagi oleh Pasal 10 ayat (2) UU 24/2003, kewajiban Mahkamah Konstitusi adalah memberikan keputusan atas pendapat DPR bahwa Presiden dan/atau Wakil Presiden telah melakukan pelanggaran hukum, atau perbuatan tercela, atau tidak memenuhi syarat sebagai Presiden dan/atau Wakil Presiden sebagaimana dimaksud dalam UUD 1945.

Bagi sebuah institusi peradilan, putusan peradilan sering diibaratkan sebagai sebuah mahkota, artinya bahwa kewibawaan suatu putusan yang dikeluarkan oleh sebuah institusi peradilan terletak pada seberapa kuat dan mengikatnya suatu putusan kepada para pihak yang menjadi addressat putusan tersebut. Semakin kuat dan mengikatnya suatu putusan, maka semakin kuat pula daya paksa putusan tersebut untuk dipatuhi dan dilaksanakan oleh para pihak yang menjadi addressat putusan tersebut. Mahkamah Konstitusi sebagai salah satu pelaku kekuasaan kehakiman yang menyelenggarakan sebuah peradilan guna menegakkan keadilan juga tidak lepas dari problematika implementasi putusannya. Sebagai anak kandung reformasi, Mahkamah Konstitusi dirasakan telah memberikan harapan baru untuk menjawab kompleksitas perkembangan sistem ketatanegaraan Indonesia. Oleh karena keberadaan Mahkamah Konstitusi merupakan ikhtiar untuk melembagakan supremasi kontitusi maka oleh konstitusi pula Mahkamah Konstitusi ditentukan sebagai satu-satunya lembaga yang mempunyai kewenangan untuk menafsirkan dan mengawal kemurnian konstitusi, dan karenanya pula maka Mahkamah Konstitusi sering disebut sebagai "The sole interpreter of constitution" dan "The guardian of the constitution". (Jimly Asshiddiqie, 2012)

Dengan kewenangan yang diberikan kepada Mahkamah Konstitusi tersebut maka oleh konstitusi pula ditentukan pula bahwa sifat putusan Mahkamah Konstitusi adalah 
final. Terkait sifat putusan tersebut, Undang-Undang Mahkamah Konstitusi menentukan sebagaimana disebutkan dalam pasal 10 ayat (1) berikut penjelasan Undang-Undang Nomor 8 Tahun 2011 tentang Perubahan Undang-Undang Nomor 24 Tahun 2003 tentang Mahkamah Konstitusi yang menyatakan bahwa, "Putusan Mahkamah Konstitusi bersifat final, yakni putusan Mahkamah Konstitusi langsung memperoleh kekuatan hukum sejak diucapkan dan tidak ada upaya hukum yang dapat ditempuh. Sifat final dalam putusan Mahkamah Konstitusi dalam Undang-Undang ini mencakup pula kekuatan hukum mengikat (final and binding)”.

Dari ketentuan tersebut seharusnya sudah sangat jelas bahwa oleh karena sifat putusan Mahkamah Konstitusi adalah final dan mengikat, maka kepada para pihak yang menjadi adressat, seluruh lembaga negara, penyelenggara negara dan seluruh warga negara yang terkait dengan putusan tersebut harus mematuhi dan melaksanakannya. Hal inilah yang kemudian memunculkan dan berlakunya asas erga omnes pada putusan Mahkamah Konstitusi karena Putusan Mahkamah Konstitusi merupakan putusan yang tidak hanya mengikat para pihak (inter parties) akan tetapi juga harus ditaati oleh siapapun (erga omnes). Asas erga omes tercermin dari ketentuan yang menyatakan bawa putusan Mahkamah Konstitusi langsung dapat dilaksanakan dengan tidak memerlukan lagi keputusan pejabat yang berwenang kecuali peraturan perundang-undangan mengatur lain. Ketentuan tersebut merefleksikan kekuatan hukum mengikat dan karena sifat hukumnya secara publik maka berlaku pada siapa saja, tidak hanya berlaku bagi para pihak yang berperkara.

Permasalahan kemudian muncul ketika putusan Mahkamah Konstitusi acapkali tidak serta merta dilaksanakan oleh para pihak yang berperkara, lembaga negara, penyelenggara negara dan juga warga negara yang terkait dengan putusan tersebut dengan berbagai alasan. Fakta empiris menunjukkan bahwa ternyata, kekuatan dari putusan Mahkamah Konstitusi yang bersifat final dan mengikat serta berlakunya asas erga omnes dari putusan Mahkamah Konstitusi tidak dapat serta merta menjadikan putusan tersebut diimplementasikan secara konkret (non-excutiable) dan hanya mengambang (floating execution).

Paper ini akan mencoba menelah tentang sifat dan keberlakuan asas erga omnes pada suatu putusan Mahkamah konstitusi serta implementasi dari putusan Mahkamah Konstitusi.

\section{METODE PENELITIAN}

paper ini, menggunakan jenis kajian yuridis normatif. Adapun pendekatan yang digunakan ialah doktrinal dengan menekankan pendekatan filosofis, historis serta yuridis. Data dilengkapi dengan data primer dari hasil analisis UUD 1945, berbagai peraturan perundang-undangan, putusan, dan data sekunder dari referensi-referensi (buku, artikel, karya ilmiah, jurnal, media cetak, majalah dan website), serta data tersier, dalam hal ini, dengan menggunakan Kamus Besar Bahasa Indonesia, dan diolah dengan metode analisis kualitatif secara deduktif

\section{PEMBAHASAN}

Secara normatif-yuridis, putusan Mahkamah Konstitusi bersifat final dan mengikat sejak diucapkan dalam sidang pleno yang terbuka untuk umum. Artinya, sejak memiliki kekuatan hukum tetap, tidak ada upaya hukum lanjutan berupa banding dan kasasi, termasuk juga upaya untuk mengoreksi, putusannya merupakan tingkat pertama sekaligus terakhir. Konsekuensinya, putusan Mahkamah Konstitusi tidak boleh dianulir atau bahkan diabaikan. Putusan Mahkamah Konstitusi bersifat final dan mengikat, dengan kata lain tidak ada upaya hukum lain. Mengenai sifat final putusan Mahkamah Konstitusi juga ditegaskan dalam pasal 24 C ayat (1) UUD 1945. Berdasarkan ketentuan 
di atas maka putusan Mahkamah Konstitusi bersifat final yang berarti: (1) secara langsung memperoleh kekuatan hukum, (2) karena telah memperoleh kekuatan hukum tetap maka putusan Mahkamah Konstitusi memiliki akibat hukum bagi semua pihak yang berkaitan dengan putusan. Hal ini menunjukkan bahwa putusan Mahkamah Konstitusi berbeda dengan putusan peradilan umum yang hanya mengikat para pihak berperkara (interparties). Semua pihak wajib mematuhi dan melaksanakan putusan Mahkamah Konstitusi (erga omnes), (3) karena merupakan pengadilan pertama dan terakhir, maka tidak ada upaya hukum lain yang dapat ditempuh. Sebuah putusan yang apabila tidak ada upaya hukum yang dapat ditempuh berarti telah mempunyai kekuatan hukum tetap (in kracht van gewijsde) dan memperolah kekuatan mengikat (resjudicata pro veritate habeteur). Tegasnya, putusan Mahkamah Konstitusi yang telah memiliki kekuatan hukum tetap dengan serta merta memiliki kekuatan hukum mengikat untuk dilaksanakan. (Fajar Laksono, 2013; 9)

Asas putusan mengikat secara erga omnes tersebut di atas tercermin melalui kalimat sifat final dalam putusan Mahkamah Konstitusi dalam Undang-Undang ini mencakup pula kekuatan hukum mengikat (final and binding). Erga omnes berasal dari bahasa latin yang artinya berlaku untuk setiap orang (toward every one). Asas erga omnes atau perbuatan hukum adalah berlaku bagi setiap individu, orang atau negara tanpa perbedaan (A erga omnes law or legal act applies as against every individual, person or state without distinction). (Erga Omnes Definition, www.duhaime.org) Suatu hak atau kewajiban yang bersifat erga omnes dapat dilaksanakan dan ditegakkan terhadap setiap orang atau lembaga, jika terjadi pelanggaran terhadap hak tersebut atau tidak memenuhi suatu kewajiban.

Dalam realitas empirik, masalah implementasi putusan Mahkamah Konstitusi seringkali mengalami kesulitan, setidaknya menunjukkan banyak variasi masalah dan pola implementasinya. Persoalan implementasi putusan Mahkamah Konstitusi setidaknya disebabkan oleh 3 (tiga) hal yaitu: (1) sebagaimana dituangan dalam Pasal 24 C ayat (1) UUD RI 1945, putusan Mahkamah Konstitusi hanya bersifat final akan tetapi tidak disertai kata mengikat sehingga terkadang dipersepsikan tidak mengikat; (2) Mahkamah Konstitusi tidak memiliki unit eksekutor yang bertugas menjamin aplikasi putusan final (special enforcement agencies); dan (3) putusan final sangat bergantung pada cabang kekuasaan negara yang lain yakni eksekutif dan legislatif, yaitu kerelaan dan kesadaran untuk melaksanakan putusan. Dari ketiga hal tersebut di atas, tampak jelas bahwa di lapangan, putusan Mahkamah Konstitusi sangat rentan dan berpotensi mengalami masalah implementasi. Dalam hal ini, semata-mata menggantungkan pada ketentuan normatif dan imperatif baik dalam UUD 1945, undang-undang Mahkamah Konstitusi maupun putusan Mahkamah Konstitusi, belumlah cukup menjamin tidak adanya persoalan dalam implementasi putusan. Ketentuan normatif imperatif mengenai sifat final dan keberlakuan putusan Mahkamah Konstitusi tidak serta merta menghilangkan hambatan dalam implementasinya. Sebab dalam kenyataannya, putusan Mahkamah Konstitusi tidak akan dapat ditegakkan manakala dipahami sebagai entitas yang berdiri sendiri, terpisah dari interaksinya dengan hal di luar itu. (Fajar Laksono, 2013; 4)

Tidak dilaksanakannya putusan Mahkamah Konstitusi dapat dilihat dari contoh beberapa putusan Mahkamah Konstitusi yang tidak serta merta direspon oleh para pihak yeng terkait dengan putusan tersebut yakni dari penyelenggara negara dan lembaga negara baik dari cabang kekuasaan eksekutif, legislatif, yudikatif yaitu Mahkamah Agung (MA) sebagai addressat putusan tersebut antara lain:

1. Putusan Mahkamah Konstitusi yang tidak dilaksanakan oleh MA misalnya adalah Putusan Nomor 34/PUU-XI/2013 yang membatalkan Pasal 268 ayat (3) KUHAP. Akibat hukum dari putusan tersebut yaitu bahwa Peninjauan Kembali (PK) dapat 
diajukan oleh terpidana atau ahli warisnya lebih dari sekali selama masih memenuhi syarat-syarat yang ditentukan dalam Pasal 268 ayat (2) KUHAP. Putusan Mahkamah Konstitusi ini kemudian dianulir oleh MA melalui Surat Edaran Mahkamah Agung (SEMA) Nomor 07 Tahun 2014 tentang Pengajuan Permohonan Peninjauan Kembali Dalam Perkara Pidana. Substansi dari SEMA tersebut adalah untuk menegaskan bahwa PK hanya dapat dilakukan 1 (satu) kali.

2. Putusan Mahkamah Konstitusi yang tidak dilaksanakan oleh cabang kekuasaan eksekutif secara konsekuen yaitu Putusan Nomor 5/PUU-X/2012 tentang pengujian Pasal 50 ayat (3) Undang-Undang Nomor 20 Tahun 2003 tentang Sistem Pendidikan Nasional. Persoalan implementasi putusan Mahkamah Konstitusi pada konteks ini yaitu pemerintah melalui Kementerian Pendidikan dan Kebudayaan masih menempuh kebijakan masa transisi untuk menghapus kebijakan Sekolah Bertaraf Internasional (SBI) dan/atau Rintisan Sekolah Bertaraf Internasional (RSBI). (Fajar Laksono, 2013; 5) Padahal hakikatnya, Putusan Mahkamah Konstitusi tidak mengenal masa transisi untuk dilaksanakan, namun mempunyai kekuatan hukum mengikat sejak diucapkan, yang artinya sejak saat itu pula harus dipatuhi dan diimplementasikan.

3. Putusan yang tidak dilaksanakan oleh cabang kekuasaan legislatif misalnya adalah Putusan Nomor 011/PUU-III/ 2005 yang menyatakan bahwa penjelasan Pasal 49 ayat (1) Undang-Undang Sistem Pendidikan Nasional (UU Sisdiknas) tidak mempunyai kekuatan hukum mengikat. Pada putusan tersebut Mahkamah Konstitusi berpendapat bahwa pada hakikatnya pelaksanaan konstitusi tidak boleh ditundatunda, termasuk ketentuan anggaran minimal 20 persen dari APBN untuk pendidikan telah dinyatakan secara expres verbis, sehingga tidak boleh direduksi oleh peraturan perundang-undangan di bawahnya. Namun, pada undang-undang yang lain yaitu Undang-Undang tentang APBN Tahun 2005 panitia anggaran DPR hanya mengalokasikan anggaran sebesar 36 Triliun atau setara dengan 8,1 persen dari total anggaran yang ada. (APBN, 2006)

Beberapa contoh di atas menunjukkan bahwa putusan Mahkamah Konstitusi mempunyai ketegasan hanya pada tataran normatif saja. Putusan Mahkamah Konstitusi hanya tampak populis serta progresif di permukaan, namun justru tidak jarang putusannya 'gagal' melimpahkan keadilan dan kepastian hukum karena berhenti pada putusan normatif yang tidak sepenuhnya diimplementasikan secara konsekuen oleh lembaga yang terkena adressat putusan. Hal ini terutama berkaitan erat dengan putusan yang berada dalam ranah judicial review atau pengujian undang-undang. Sebaliknya, implementasi putusan Mahkamah Konstitusi sangat tergantung pada cabang kekuasaan lain baik legislatif, eksekutif maupun yudikatif yakni Mahkamah Agung. Keadaan tersebut tentu telah sangat jelas menunjukkan bahwa keberadaan Mahkamah Konstitusi hingga saat ini belum mempunyai daya tawar yang kuat sebagai satu-satunya lembaga tinggi negara yang mempunyai otoritas mengawal sekaligus menafsirkan konstitusi. Terlebih keberadaan Mahkamah Konstitusi memang tidak mempunyai ranah dan wewenang untuk ikut andil dalam proses implementasi putusannya sendiri. Tidak salah apabila dikatakan bahwa Mahkamah Konstitusi merupakan cabang kekuasaan dalam struktur ketatanegaraan yang paling lemah di antara cabang-cabang kekuasaan negara lainnya (the least dangerous power, with no purse nor sword) (Alexander Hamilton, 2015). Apabila keadaan tersebut terus dibiarkan, perkembangan dan kedudukan Mahkamah Konstitusi dalam struktur ketatanegaraan di Indonesia hanya akan menjadi formalitas belaka, di samping juga tingkat kepercayaan publik terhadap Mahkamah Konstitusi akan menurun. Pada gilirannya, Mahkamah Konstitusi kehilangan marwah sebagai lembaga penafsir dan pengawal konstitusi sebagaimana original intent dibentuknya Mahkamah Konstitusi. 
Konsekuensi logis dari hal tersebut, Mahkamah Konstitusi akan ditinggalkan oleh para pencari keadilan.

Sebagai salah satu pelaku kekuasaan kehakiman, secara filosofis independensi kekuasaan kehakiman adalah kekuasaan yang bebas dari segala bentuk intervensi baik dari dalam maupun dari luar kekuasaan kehakiman, kecuali atas dasar Pancasila dan UUD 1945. Nilai-nilai falsafah Pancasila sebagai pandangan hidup bangsa adalah hukum dasar dan hukum operasional bagi eksistensi independensi kekuasaan kehakiman sebagai prasyarat tegaknya hukum dan keadilan yang dicita-citakan. Tujuan utama kekuasaan kehakiman menurut UUD Tahun 1945 sejalan dengan tujuan negara yang termuat dalam alinea ke-4 UUD Tahun 1945, salah satunya adalah melindungi segenap bangsa Indonesia. (https: / www.bphn.go.id )

Mahkamah Konstitusi sebagai salah satu pelaku kekuasaan kehakian mempunyai peranan penting guna menegakkan konstitusi dan prinsip negara hukum sesuai dengan kewenangan dan kewajibannya sebagaimana ditentukan dalam UUD Tahun 1945. Dalam mencapai peran tersebut, Mahkamah Konstitusi harus menjadi institusi yang independen untuk mewujudkan keadilan dan kepastian hukum, menjalankan fungsi check and balances bagi lembaga negara lainnya, dan mengakkan prinsip negara hukum yang demokratis serta mewujudkan kedaulatan rakyat.

Selain itu, Mahkamah Konstitusi mempunyai fungsi untuk mengawal (to guard) konstitusi agar dilaksanakan dan dihormati baik penyelenggara kekuasaan negara maupun warga negara. Mahkamah Konstitusi juga sebagai penafsir akhir konstitusi. Di berbagai negara Mahkamah Konstitusi juga menjadi pelindung (protector) konstitusi. Sejak di-inkorporasi-kannya hak-hak asasi manusia dalam Undang Undang Dasar 1945, bahwa fungsi pelindung konstitusi dalam arti melindungi hak-hak asasi manusia (fundamental rights) juga benar adanya. Tetapi dalam penjelasan Undang-undang Nomor 24 Tahun 2003 tentang Mahkamah Konstitusi dinyatakan sebagai berikut: “... salah satu substansi penting perubahan Undang-Undang Dasar Negara Republik Indonesia Tahun 1945 adalah keberadaan Mahkamah Konstitusi sebagai lembaga negara yang berfungsi menangani perkara tertentu di bidang ketatanegaraan, dalam rangka menjaga konstitusi agar dilaksanakan secara bertanggung jawab sesuai dengan kehendak rakyat dan cita-cita demokrasi. Keberadaan Mahkamah Konstitusi sekaligus untuk menjaga terselenggaranya pemerintahan negara yang stabil, dan juga merupakan koreksi terhadap pengalaman kehidupan ketatanegaraan di masa lalu yang menimbulkan tafsir ganda terhadap konstitusi”. (https://mkri.id/)

Secara historis, upaya pembentukan Mahkamah Konstitusi adalah salah satu wujud nyata perubahan sistem ketatanegaraan, sehingga tercipta keseimbangan dan kontrol yang ketat di antara lembaga-lembaga negara. Meski demikian, hakikat pembentukan Mahkamah Konstitusi selain lebih mempertegas prinsip negara hukum dan perlindungan hak asasi manusia yang telah dijamin konstitusi, juga sebagai sarana penyelesaian sengketa ketatanegaraan yang memerlukan lembaga atau badan yang berwenang menyelesaikannya, karena sebelumnya tidak ada dalam UUD 1945. (Iriyanto A. Baso Ence, 2008; 132) Bahwa kewenangan Mahkamah Konstitusi sebagaimana diatur dalam UUD 1945 tersebut lebih lanjut ditekankan kembali dengan ketentuan Pasal 9 Undang-Undang Nomor 12 Tahun 2011 tentang Tata Urutan Perundang-undangan yang menyatakan: “...(1) Dalam hal suatu Undang-Undang diduga bertentangan dengan Undang-Undang Dasar Negara Republik Indonesia Tahun 1945, pengujiannya dilakukan oleh Mahkamah Konstitusi. (2) Dalam hal suatu Peraturan Perundang-undangan di bawah Undang-Undang diduga bertentangan dengan Undang-Undang, pengujiannya dilakukan oleh Mahkamah Agung." 
Perubahan UUD 1945 menempatkan Mahkamah Konstitusi sebagai lembaga negara dalam sistem ketatanegaraan Indonesia. Lembaga negara ini diharapkan berfungsi untuk melaksanakan kekuasaan peradilan dalam sistem konstitusi, pengawal konstitusi (the Guardians of the Constitution) dan penafsir konstitusi yang kompeten dalam kehidupan bernegara. Di samping itu, lembaga negara ini juga lebih berperan mendorong mekanisme checks and balances dalam penyelenggaraan negara dan berperan pula dalam mewujudkan negara hukum yang demokratis. (Fajar Laksono Soeroso, 2014).

Pembahasan Makna Final dan Mengikat Putusan Mahkamah Konstitusi Mengetahui makna dan sifat putusan Mahkamah Konstitusi, juga penting untuk menganalisis sejarah munculnya klausul pengaturan tersebut, guna mengetahui original intent para perumusnya. Untuk dapat dimengerti secara sungguh-sungguh maksud ketentuan UUD dari suatu negara, perlu dipelajari bagaimana proses terjadinya teks tersebut, harus dipahami keterangan-keterangannya, dan juga harus diketahui dalam suasana apa teks tersebut dirumuskan. Dengan demikian, akan diketahui maksud ketentuan undangundang, bahkan peristiwa atau pikiran apa yang mendasari dan melingkupinya.

Sifat putusan MK pertama kali diatur di dalam UUD 1945 setelah perubahan ketiga, tepatnya Pasal 24C ayat (1) yang menyatakan "Mahkamah Konstitusi berwenang mengadili pada tingkat pertama dan terakhir yang putusannya bersifat final...". Pembahasan mengenai makna dari sifat putusan MK pada prosesperubahan UUD 1945 ini tidak dibahas secara mendetail, bahkan dapat dikatakan sangat jarang sekali dibahas apalagi diperdebatkan.

Valina Singka Subekti menyatakan, mengenai kewenangan Mahkamah Konstitusi pada proses perumusan Mahkamah Konstitusi di Indonesia, bahwa penyelesaian perkara di lingkungan Mahkamah Konstitusi harus dilakukan dalam waktu yang cepat, dan tidak sepenuhnya perkara di Mahkamah Konstitusi dapat dijangkau oleh lingkungan peradilan umum. Atas dasar ini, putusan Mahkamah Konstitusi harus diletakkan sebagai putusan tingkat pertama dan terakhir. ${ }^{1} \mathrm{Hal}$ ini bahkan menurut Pattaniari Siahaan mempunyai korelasi dengan jumlah hakim konstitusi. Bahwa formulasi hakim konstitusi berjumlah 9 orang dimaksudkan agar persidangan bisa singkat cepat tetapi representatif, mengingat sidang Mahkamah Konstitusi merupakan pertama dan terakhir.

Esensi yuridis dari putusan Mahkamah Konstitusi yang bersifat final adalah memiliki kekuatan mengikat sesuai dengan asas erga omnes dalam kekuasaan kehakiman yaitu mengikat secara umum semua pihak termasuk mengikat obyek yang disengketakan sebagaimana di ungkapkan S.F. Marbun. Pada bagian lain juga mengutip pendapat Bagir Manan pada saat kuliah umum di Fakultas Hukum Universitas Atma Jaya Yogyakarta pada tanggal 19 Februari 1994 yang menyatakan bahwa: Salah satu segi positif dari putusan yang berkarakter erga omnes adalah adanya kepastian hukum mengenai kedudukan peraturan perundang-undangan atau perbuatan administrasi yang dinyatakan tidak sah. Sedangkan segi negatif berarti hakim tidak lagi semata-mata berfungsi menetapkan hukum (fungsi peradilan), tetapi telah berkembang hingga melakukan juga fungsi membentuk hukum (fungsi perundang-undangan). Penjelasan Pasal 10 ayat (1) UU No. 24 tahun 2003 menyatakan bahwa putusan Mahkamah Konstitusi bersifat final yakni putusan Mahkamah Konstitusi langsung memperoleh kekuatan hukum sejak diucapkan dan tidak ada upaya hukum yang dapat ditempuh. Konsep tersebut mengacu pada prinsip penyelenggaraan kekuasaan kehakiman yakni secara sederhana dan cepat sebagaimana diuraikan dalam penjelasan UU Nomor 24 Tahun 2003 tentang Mahkamah Konstitusi yang secara utuh menjelaskan bahwa: Mahkamah Konstitusi dalam menyelenggarakan peradilan untuk memeriksa, mengadili, dan memutus perkara tetap mengacu pada prinsip penyelenggaraan kekuasaan kehakiman yakni dilakukan secara sederhana dan cepat. Putusan Mahkamah Konstitusi yang final dan mengikat tersebut, tidak dapat dilepaskan 
dengan asas erga omnes yang diartikan dengan mengikat secara umum dan juga mengikat terhadap obyek sengketa. Apabila suatu peraturan perundang-undangan oleh hakim menyatakan tidak sah, karena bertentangan dengan peraturan perundang-undangan yang lebih tinggi, berarti peraturan perundang-undangan tersebut berakibat menjadi batal dan tidak sah untuk mengikat setiap orang. Putusan Mahkamah Konstitusi memiliki kekuatan mengikat secara hukum terhadap semua komponen bangsa termasuk obyek yang disengketakan.

Masih terkait dengan sifat putusan final dan mengikatnya putusan Mahkamah Konstitusi, menurut Fajar Laksono, landasan yang mendasari putusan Mahkamah Konstitusi merupakan putusan pada tingkat pertama sekaligus tingkat terakhir ini setidaknya dapat dilihat dari 2 alasan mendasar. Pertama, putusan Mahkamah Konstitusi bersifat final bukan hanya semata-mata bahwa Mahkamah Konstitusi merupakan satusatunya lembaga peradilan yang menjalankan kewenangannya, dalam arti bahwa tidak ada lembaga lain atau bahkan lembaga peradilan yang lebih tinggi yang juga mempunyai kewenangan serupa dengan Mahkamah Konstitusi, namun lebih dari itu, putusan Mahkamah Konstitusi dilekatkan pada hakikat kedudukan konstitusi sebagai hukum tertinggi sehingga tidak ada hukum lain yang kedudukannya lebih tinggi dari pada itu. Hal ini disebabkan karena perkara yang dihadapkan pada Mahkamah Konstitusi untuk diselesaikan, dan menjadikan konstitusi sebagai batu uji atau dasar pengujiannya, maka hasil akhir atau putusan dari perkara tersebut mutlak bersifat final, karena tidak dimungkinkan lagi untuk dilakukan upaya lebih lanjut, serta batu uji yang lebih tinggi selain konstitusi. Artinya, putusan Mahkamah Konstitusi yang bersifat final merupakan konsekuensi logis dari sebuah negara hukum yang meletakkan konstitusi sebagai hukum tertingginya. Kedua, putusan Mahkamah Konstitusi yang bersifat final merupakan upaya untuk menjaga dan melindungi wibawa peradilan konstitusional. Alasan mendasar pada pendapat ini yaitu, jika peradilan konstitusi mengakomodasi adanya upaya hukum, maka tentu tidak ada bedanya dengan peradilan umum, yang biasanya sebuah perkara diajukan upaya hukum terhadap putusannya akan memakan waktu yang sangat panjang. Akibatnya adalah, para pihak akan mengalami ketersanderaan, baik waktu, tenaga, maupun biaya, yang kesemuanya bertentangan dengan asas peradilan yang diselenggarakan secara cepat, sederhana, dan biaya ringan. Jenedjri M. Gaffar berpendapat, bahwa putusan yang adil pun akan kehilangan makna apabila diputus dalam waktu yang lama dan tidak dapat segera diakses oleh masyarakat yang berhak (justice delayed, justice denied).

Pada aspek kepastian hukum, persoalan implementasi putusan Mahkamah Konstitusi sebagaimana dijelaskan di atas tentu menjadi permasalahan yang sangat fundamental. Mahkamah Konstitusi sebagai pengawal konstitusi dan bentuk dari pelembagaan menuju supremasi konstitusi tentu akan jauh dari cita-citanya. Dapat dikatakan bahwa diimplementasikannya putusan Mahkamah Konstitusi secara konsekuen merupakan indikator utama tegaknya supremasi konstitusi. Pada ruang lingkup yang lebih luas, hal tersebut merupakan cerminan atas tegaknya negara hukum. Putusan Mahkamah Konstitusi hanya menjadi macan kertas, tidak implementatif dan dapat mencederai pemahkotaan supremasi hukum.

Dengan demikian, nilai mengikat dari putusan Mahkamah Konstitusi yang final adalah sama dengan nilai mengikat dan sebuah undang-undang hasil produk politik, yang berfungsi sebagai alat rekayasa sosial politik, alat kontrol terhadap masyarakat dan penguasa serta memberikan perlindungan hukum terhadap seluruh komponen bangsa. 


\section{PENUTUP}

Hasil kajian pada paper ini menghasilkan simpulan bahwa, pertama, karakteristik utama putusan mengikat Mahkamah Konstitusi yaitu sifatnya yang erga omnes, yaitu sebuah putusan yang akibat hukumnya mengikat semua pihak. Hal ini dikarenakan sifat norma dalam bentuk undang-undang yang diuji dan norma yang dijadikan dasar pengujian yaitu konstitusi, adalah norma yang bersifat umum (abstract and impersonal). Asas putusan mengikat secara erga omnes tersebut di atas tercermin melalui kalimat sifat final dalam putusan Mahkamah Konstitusi dalam Undang-Undang ini mencakup pula kekuatan hukum mengikat (final and binding). Kedua, sifat putusan Mahkamah Konstitusi adalah final dan mengikat, final berarti bahwa putusan Mahkamah Konstitusi merupakan upaya yang pertama (the first resort) sekaligus upaya terakhir (the last resort) yang mempunyai konsekuensi tidak ada upaya hukum lebih lanjut yang dapat ditempuh terhadap putusan tersebut, dan karenanya secara langsung mempunyai kekuatan hukum tetap. Ketiga, beberapa faktor terkait dengan tidak diimplementasikannya putusan Mahkamah Konstitusi oleh semua pihak yang menjadi addressat putusan tersebut antara lain karena (i) kedudukan Mahkamah Konstitusi hanya sebagai negative legislature, (ii) tidak adanya special enforcement agencies, (iii) tidak adanya tenggang waktu untuk mengimplementasikan putusan, (iv) tidak adanya konsekuensi hokum atas pengabaian terhadap putusan Mahkamah Konstitusi.

Oleh karena itu, guna menciptakan putusan final dan mengikat yang implementatif, tentu berangkat dari analisis dan kerangka konseptual sebagaimana dijelaskan di atas, maka penulis mencoba menyampaikan saran sebagai berikut: Bahwa tugas peradilan konstitusi tidak sekadar menyelenggarakan aktivitas interpretasi, tetapi juga memikul tanggungjawab besar agar ketentuan-ketentuan konstitusi implementatif. Implementasi adalah fungsi yang memerlukan tindakan kolaboratif dan koordinatif sehingga proses pengejewantahan kaidah-kaidah konstitusi dalam kehidupan nyata tidak bisa diwujudkan tanpa ada tindakan dan kesepakatan kolektif dari penyelenggara negara, Lembaga negara serta masyarakat warga negara. Richard H. Fallon dalam Implementation the Constitution mengatakan: "If we the Court central role as implementing the Constitution, we can better understand why the Justice sometimes must compromise their own view about what would be best in order to achieve coherent, workable constitutional doctrine"

\section{DAFTAR PUSTAKA}

\section{Buku}

Alexander Hamilton, "The Federalist Paper" Dalam Maruarar Siahaan, Undang-Undang Dasar 1945 Konstitusi Yang Hidup, Sekretariat Jenderal dan Kepaniteraan Mahkamah Konstitusi, Jakarta, 2008

Fajar Laksono dkk, Implikasi dan Implementasi Putusan Mahkamah Konstitusi Nomor 5/PUU-X/2012 tentang Sekolah Bertaraf Internasional (SBI)/ Rintisan Sekolah Bertaraf Internasional (RSBI), Pusat Penelitian dan Pengkajian Perkara, Pengelolaan Teknologi Informasi dan Komunikasi Kepaniteraan dan Sekretariat Jenderal Mahkamah Konstitusi Republik Indonesia, 2013.

Jimly Asshiddiqie, Perkembangan \& Konsolidasi Lembaga Negara Pasca Reformasi, Edisi Kedua, Cetakan Kedua, Sinar Grafika, Jakarta, 2012.

Iriyanto A. Baso Ence, 2008, Negara Hukum Dan Hak Uji Konstitusionalitas Mahkamah Konstitusi, Makasar: PT Alumni.

Janedjri M. Gaffar, “MK: Menegaskan Keadilan Substantif” Seputar Indonesia, 13 Agustus 2009.

Jimly Asshiddiqie, Perkembangan \& Konsolidasi Lembaga Negara Pasca Reformasi, Edisi Kedua, Cetakan Kedua, Sinar Grafika, Jakarta, 2012. 
Mohammad Agus Maulidi, Problematika Hukum Implementasi Putusan Final dan Mengikat Mahkamah Konstitusi Perspektif Negara Hukum.

Richard H. Fallon, JR. Implementing The Constitution, (Cambridge: Harvard University Press, 2001), hlm. 37. Dalam Dr. Inosentius Samsul, S.H, M.H. dkk, Pengkajian Hukum Tentang Putusan Mahkamah Konstitusi, Badan Pembinaan Hukum Nasional Kementerian Hukum Dan HAM RI, 2009.

Tim Penyusun Naskah Komprehensif Proses dan Hasil Perubahan UUD 1945, Naskah Komprehensif Perubahan Undang-Undang Dasar Negara Republik Indonesia: Buku VI, Kekuasaan Kehakiman, Edisi Revisi, Sekretariat Jenderal dan

Jurnal Kepaniteraan Mahkamah Konstitusi, Jakarta, 2010.

Ahmad Syahrizal, "Problem Implementasi Putusan MK" Jurnal Konstitusi, Volume 4, Nomor 1, Maret 2007

Fajar Laksono Soeroso, "Aspek Keadilan Dalam Sifat Final Putusan Mahkamah Konstitusi" Jurnal Konstitusi, Volume 11, Nomor 1, Maret 2014.

S. F. Marbun, dalam Malik, SH.,MH. Telaah Makna Hukum Putusan Mahkamah Konstitusi yang Final dan Mengikat, Jurnal Konstitusi, Volume 6 Nomor 1, April 2009,

\section{Internet}

Anonim, “APBN 2006, Pemerintah dan DPR Abaikan Putusan MK" dalam http://www.hukumonline.com/ berita/baca/hol13876/apbn-2006pemerintah-dan-dpr-abaikan-putusan-mk, diakses pada tanggal 05 Mei 2017.

Badan Pembina Hukum Nasional, "Naskah Akademik Rancangan Undang-Undang Tentang Mahkamah Konstitusi" (tanpa tahun), <.https://www.bphn.go.id/data/documents/na_ruu_revisi_uu_mk.pdf>, [24/07/2019].

Erga Omnes Definition, http://www.duhaime.org/LegalDictionary/E/ErgaOmnes.aspx, diakses pada tanggal 8 Oktober 2017.

Mahkamah Konstitusi, "Sejarah dan Pembentukan, Kedudukan, Serta Kewenangan Mahkamah Konstitusi" <https://mkri.id/index.php?page=web.Berita\&id=11768>, [29/07/2019. 